\title{
Comparison between anal cytology, high-resolution anoscopy and HPV DNA genotyping by polymerase chain reaction in the post- treatment follow-up of condylomata acuminata
}

\section{Comparação entre citologia anal, colposcopia anal e genotipagem do HPV por reação em cadeia da polimerase no seguimento pós-operatório de condiloma acuminado}

Luis Roberto Nadal, TCBC-SP(iD); Sarhan Sydney SaAd"; Gaspar Jesus lopes Filho, TCBC-SP'; Helena Passarelli Giroud Joaquim²; Thiago da Silveira Manzione, TCBC-SP3; Carmen Ruth Manzione, TCBC-SP3; Sidney Roberto Nadal, TCBC-SP33.

\begin{abstract}
A B S T R A C T
Aim: to evaluate the presence of subclinical HPV-induced anal lesions with anal cytology, High-Resolution Anoscopy (HRA) and HPV genotyping by polymerase chain reaction (PCR) in the follow-up of treated condylomata acuminata (CA). Methods: seventy-nine male patients were included. One month after anal CA eradication, the patients underwent brush samples collection for anal cytology and PCR, and HRA with biopsy of acetowhite lesions. These methods were compared within all patients and between groups, according to Human Immunodeficiency Virus (HIV) infection status: HIV-negative; HIV-positive with TCD4 count above and below 350 cells/mm3. Results: the most frequent HPV types were 6 and 16. HPV DNA was isolated in 92\%. HIV infection was associated with a higher number of oncogenic HPV types ( $p=0.038$ ). All patients with negative PCR had negative HRA and cytology. There were no differences in cytological, HRA or histopathological findings between groups. Conclusion: the association of the findings of cytopathology, HRA and genotyping of HPV refined the diagnosis of HPV-induced lesions. The degree of immunodeficiency was not associated with increase in remnant HPV-induced anal lesions.
\end{abstract}

Keywords: Papillomavirus Infection. Anal Canal. Condylomata Acuminata. Polymerase Chain Reaction. High-Resolution Anoscopy. Anal Intraepithelial Neoplasia.

\section{INTRODUCTION}

$\mathrm{H}$ uman Papillomavirus (HPV) is the most common agent of sexually transmitted infections(STI)1. It is responsible for anorectal lesions such as condylomata acuminata (CA), squamous cell carcinoma (SCC) and its precursor, intraepithelial neoplasia ${ }^{1,2}$. CA is usually the first clinical manifestation of the STI, and it triggers the workup to diagnose and treat concurrent infections such as the one by the Human Immunodeficiency Virus (HIV).

Treatment methods for CA are potentially expensive, time-consuming and not without complications. Recurrence rates are up to $88 \%$, depending on the used therapeutic method ${ }^{2,3}$. HPV 6 and 11 are low-risk types associated to most of the CA cases, and they are linked to coinfection with other HPV types in about $50 \%$ of the lesions ${ }^{4}$, including high-risk types associated to anogenital SCC ${ }^{4-6}$. Treatment of CA does not eradicate the virus at the site of infection ${ }^{2,3}$, and coinfection with other HPV types, mainly HPV 16, can be considered a risk factor for the development of anal SCC 1,7 . Post-eradication follow-up of CA patients aims at, besides preventing recurrence, screening patients at risk for SCC precursors.

The workups to be performed during the follow-up are questionable and challenging. Current practice on screening for anal intraepithelial neoplasia

1 - UNIFESP - Escola Paulista de Medicina, Pós-Graduação em Ciência Cirúrgica Interdisciplinar - São Paulo - SP - Brasil 2 - Universidade de São Paulo, Laboratório de Investigação Médica 27 - São Paulo - SP - Brasil 3 - Instituto de Infectologia Emilio Ribas, Equipe Técnica de Proctologia - São Paulo - SP - Brasil 
(AIN) with the objective of preventing anal squamous cell carcinoma (SCC) includes anal cytology, high-resolution anoscopy (HRA) ${ }^{6}$, and, more recently, HPV genotyping, which makes the investigation of these other HPV manifestations also challenging ${ }^{2}$.

The ideal method for screening referred by most authors is the HRA due to the high incidence of false negatives in the anal cytology ${ }^{2}$. Others have stated that its association with cytology adds effectivity3. HPV DNA genotyping tests have already been assessed for the screening of precursor lesions of anal SCC ${ }^{4}$. However, no study has shown these methods as CA follow-up of to reduce recurrence of warts. The current literature is not clear which the best single or combination test to detect subclinical remnant lesions are. Furthermore, whether the immune status may predispose to higher grade dysplastic lesions is also questionable.

Our aim is to evaluate whether the association of anal cytopathology, HRA and HPV DNA genotyping increases the sensitivity of diagnosis of the remnant HPV-induced subclinical lesions in MSM, as well as to verify if PCR genotyping has similar findings to the association between HRA and cytological examinations. Along with them, we ought to determine if the degree of immunodeficiency is associated with the increase of the remnant HPV-induced anal lesions.

\section{PATIENTS AND METHODS}

Seventy-nine male patients older than 18 years from the colorectal outpatient clinic of our institution, were included after treatment of biopsy-confirmed condylomata acuminata of the anal margin and/or canal, from June 2015 to June 2017. This study was approved by the research board under the Brazilian National Ethics Approval numbers 67182316.6.0000.0061 and 67182316.6.3001.5505, and protocol numbers 2.274.432 and 2.336.126.

We excluded those receiving chemo and/or radiotherapy or with previous surgical or radiotherapy treatment for SCC of the anorectal region, or HIV positive patients not using or with irregular highly active antiretroviral therapy (HAART) use.

The treatment was performed according to the institute's protocol described by Manzione et al. ${ }^{3}$, which consists of treating lesions external to the pectineal line with $25 \%$ podophyllin solution in solid Vaseline or $90 \%$ trichloroacetic acid in the proximal anal canal, after specimen retrieval for histological confirmation of CA. Up to four applications were performed. The residual warts were removed by surgical resection, under local anesthesia or rachianesthesia, using scissors and electrocauterization of the small lesions and bleeding points. Patients with no clinical signs of CA or other HPV-related anorectal disease after 30 days of the initial treatment were included from the study, receiving the proper information and signing a study Informed Consent Term before the collection of samples.

Shortly after the inspection of the anal margin for confirmation of the absence of lesions, three cellular samples were acquired by inserting a Cytobrush into the anal canal up to four centimetres from the anal border, and these were retrieved by doing five rotational movements.

The first Cytobrush sample was stored in a ThinPrep tube with $20 \mathrm{~mL}$ PreservCyt solution (Hologic, USA). HPV DNA extraction was done according to the QIAmp DNA Mini Kit protocol (Qiagen, Japan), and the specimens tested for the presence of HPV by Linear Array following manufacturer's instructions (Roche Diagnostics, Switzerland), and amplified samples by use of the PerkinElmer GeneAmp PCR System 9700 according to the linear matrix protocol. We classified as oncogenic HPV types 16 , $18,26,31,33,35,39,45,50,51,52,53,55,56,58$, $59,66,68,73$ and $82^{5}$. We were not able to perform the genotyping tests in four patients due to unavailability of kits. However, data from those subjects were used to carry out other analysis.

The other two obtained samples were brushed on a histological glass and immediately fixed in ethanol, then underwent Pap testing using standard cytopathology laboratory equipment and analysed by two expert cytopathologists from the Institute. The highest observed degree of dysplasia between the samples was considered. All positive acetowhite lesions detected by HRA were biopsied for histological confirmation.

All HRAs were performed by the same professional. After the initial inspection, a gauze soaked in $3 \%$ acetic acid solution was applied to perianal skin. Within two to three minutes, the examination was performed with the magnification to search for whitish lesions that 
contrasted with the adjacent squamous epithelium, referred as acetowhite. The differentiation of scar ring lesions was made by the use of the $1 \%$ toluidine blue solution. Then, the dentate line was located by anoscopy, and another soaked gauze was placed for two minutes, with subsequent investigation of the acetowhite lesions of the anal canal, with the colposcope. All acetowhite lesions were considered positive examination and biopsied for histological confirmation.

Low Anogenital Squamous Terminology (LAST) classification ${ }^{5}$ was followed. We classified the normal finding as negative cytology, and positive the other cytopathological findings (ASCUS, ASC-H, LSIL and HSIL). The histopathological findings were classified as normal when chronic non-specific inflammatory process, and both HSIL and LSIL were seen as positive biopsy. Two biopsy samples were lost and excluded from this analysis.

Three groups of individuals were assessed according to the immunological status: (I) 20 HIV-negative patients, mean age 34.3 years; (II) 40 HIV-positive patients with CD4 T-lymphocyte count above 350 cells $/ \mathrm{mm3}$, mean age 39.2 years; (III) 19 HIV-positive patients with CD4 T-lymphocyte count below 350 cells/mm3, mean age 45.8 years. There was a difference between the groups regarding age $(p=0.022)$.

We named CytoHRA the association between HRA and cytological examinations. Individuals with any positive HRA or positive cytology were grouped as positive CytoHRA, and both normal findings, negative CytoHRA. Sensitivity of the methods were analysed using the HRAguided biopsies as gold standard.

The statistical analysis was performed using SPSS v.22 (IBM Analytics, Armonk, USA), using chi-square tests for categoric variables and Pearson or t-test for the continuous, considering 95\% confidence interval. When there was a statistic difference, post-hoc Bonferroni test was added. Comparison between methods was calculated using Kappa Index, and the results were evaluated according to Landis and Loch' .

\section{RESULTS}

No differences between groups were found regarding cytology, HRA (Table 1) or guided biopsies (Table 2). Forty-six (58.2\%) HRA were positive for acetowhite lesions and biopsied. Histologic low-grade squamous intraepithelial lesions (LSIL) were detected in 26 (59.1\%) of the biopsies and HSIL in 2 (4.5\%), both in HIV seropositive patients, one in each group.

Table 1. Total frequency of anal canal cytology and High-Resolution Anoscopy findings after one-month-follow-up posttreatment of margin and/or anal canal lesions.

\begin{tabular}{|c|c|c|c|c|}
\hline \multirow{2}{*}{$\begin{array}{l}\text { Cytology } \\
\text { Finding }\end{array}$} & \multicolumn{3}{|c|}{ GROUP } & \multirow{2}{*}{$p$} \\
\hline & Group I & Group II & Group III & \\
\hline Inconclusive & $\begin{array}{c}0 \\
(0.0 \%)\end{array}$ & $\begin{array}{c}3 \\
(7.5 \%)\end{array}$ & $\begin{array}{c}0 \\
(0.0 \%)\end{array}$ & \multirow{6}{*}{0.390} \\
\hline Normal & $\begin{array}{c}4 \\
(20.0 \%)\end{array}$ & $\begin{array}{c}9 \\
(22.5 \%)\end{array}$ & $\begin{array}{c}5 \\
(26.3 \%)\end{array}$ & \\
\hline ASCUS & $\begin{array}{c}6 \\
(30.0 \%)\end{array}$ & $\begin{array}{c}3 \\
(7.5 \%)\end{array}$ & $\begin{array}{c}3 \\
(15.8 \%)\end{array}$ & \\
\hline LSIL & $\begin{array}{c}10 \\
(50.0 \%)\end{array}$ & $\begin{array}{c}22 \\
(55.0 \%)\end{array}$ & $\begin{array}{c}11 \\
(57.9 \%)\end{array}$ & \\
\hline ASC-H & $\begin{array}{c}0 \\
(0.0 \%)\end{array}$ & $\begin{array}{c}2 \\
(5.0 \%)\end{array}$ & $\begin{array}{c}0 \\
(0.0 \%)\end{array}$ & \\
\hline HSIL & $\begin{array}{c}0 \\
(0.0 \%)\end{array}$ & $\begin{array}{c}1 \\
(2.5 \%)\end{array}$ & $\begin{array}{c}0 \\
(0.0 \%)\end{array}$ & \\
\hline
\end{tabular}

HRA -

Location of Group I Group II Group III Positive

\begin{tabular}{lcccc}
\hline Normal & 9 & 15 & 9 & \\
& $(45.0 \%)$ & $(37.5 \%)$ & $(47.4 \%)$ & \\
Margin & 1 & 3 & 1 & \\
& $(5.0 \%)$ & $(7.5 \%)$ & $(5.3 \%)$ & \\
Canal & 7 & 17 & 6 & 0.980 \\
& $(35.0 \%)$ & $(42.5 \%)$ & $(31.6 \%)$ & \\
Canal + & 3 & 5 & 3 & \\
Margin & $(15.0 \%)$ & $(12.5 \%)$ & $(15.8 \%)$ & \\
\hline \multirow{2}{*}{ Total } & 20 & 40 & 19 & 79 \\
& $(25.3 \%)$ & $(50.6 \%)$ & $(24.1 \%)$ & $(100 \%)$
\end{tabular}

ASCUS - Atypical squamous cells of undetermined significance; LSIL - Low grade squamous intraepithelial lesion; ASC-H - Atypical squamous cells-cannot exclude high-grade squamous intraepithelial lesion; HSIL - High grade squamous intraepithelial lesion. 
Table 2. Total frequency of findings of 44 biopsies guided by HighResolution Anoscopy one month after treatment of margin and / or anal canal lesions.

\begin{tabular}{|c|c|c|c|c|}
\hline \multirow{2}{*}{$\begin{array}{l}\text { Biopsy } \\
\text { Finding }\end{array}$} & \multicolumn{3}{|c|}{ GROUP } & \\
\hline & Group I & Group II & Group III & \\
\hline CNIP & $\begin{array}{c}2 \\
(20.0 \%)\end{array}$ & $\begin{array}{c}6 \\
(24.0 \%)\end{array}$ & $\begin{array}{c}3 \\
(33.3 \%)\end{array}$ & \multirow{4}{*}{0.896} \\
\hline Condyloma & $\begin{array}{c}1 \\
(10.0 \%)\end{array}$ & $\begin{array}{c}3 \\
(12.0 \%)\end{array}$ & $\begin{array}{c}1 \\
(11.1 \%)\end{array}$ & \\
\hline LSIL & $\begin{array}{c}7 \\
(70.0 \%)\end{array}$ & $\begin{array}{c}15 \\
(60.0 \%)\end{array}$ & $\begin{array}{c}4 \\
(44.4 \%)\end{array}$ & \\
\hline HSIL & $0(0.0 \%)$ & $\begin{array}{c}1 \\
(4.0 \%)\end{array}$ & $\begin{array}{c}1 \\
(11.1 \%)\end{array}$ & \\
\hline Total & $\begin{array}{c}10 \\
(22.7 \%)\end{array}$ & $\begin{array}{c}25 \\
(56.8 \%)\end{array}$ & $\begin{array}{c}9 \\
(20.5 \%)\end{array}$ & $\begin{array}{c}44 \\
(100 \%)\end{array}$ \\
\hline
\end{tabular}

CNIP - Chronic nonspecific inflammatory process; LGAIN- Low-grade squamous intraepithelial lesion; HSIL - High-grade squamous intraepithelial lesion.
HPV DNA was isolated in $92 \%$ of the subjects. Eighty-five percent had more than one viral type, and of these, about $76 \%$ had at least one oncogenic type. Thirty-five types of HPV were identified. Type 6 and 16 were the most frequent, isolated in $33.3 \%$ and $29.3 \%$ of the patients, respectively. Besides 16, four different oncological types were identified: 52, 53, 58 and 68 . There was no difference in the frequency of the virus types among the groups, except for types 62 and 81 , both found in $21 \%$ of the individuals in group III and in less than $5 \%$ of the others (both with $p=0.040$ ). The finding of oncogenic types was statistically similar according to HIV status ( $p=0.102$ ) (Table 3 ).

There was no difference in the total or between groups ( $p=0.468$ ) (Table 4) comparing cytology and HRA, and there was a poor Kappa-Cohen agreement $(\mathrm{K}=0.155)$. None of the patients with diagnosed histologic HSIL presented cytologic HSIL. Thirty patients (40.5\%) had negative CytoHRA, with no difference between groups ( $p$ $=0.467)$ for this test association.

Table 3. Total frequency of Human Papillomavirus Genotyping findings by Polymerase Chain Reaction one-month posttreatment of margin and/or anal canal lesions in 74 patients.

\begin{tabular}{lccccc}
\hline PCR & \multicolumn{3}{c}{ GROUP } & \multirow{2}{*}{ Total } & $p$ \\
\cline { 2 - 4 } Finding & Group I & Group II & Group III & & \\
\hline Negative & $3(17.6 \%)$ & $3(7.7 \%)$ & $0(0.0 \%)$ & $6(8.0 \%)$ & \\
Non-oncogenic & $5(29.4 \%)$ & $5(12.8 \%)$ & $2(10.5 \%)$ & $12(16.0 \%)$ & 0.102 \\
Oncogenic & $9(52.9 \%)$ & $31(79.5 \%)$ & $17(89.5 \%)$ & $57(76.0 \%)$ & \\
\hline Total & $17(22.7 \%)$ & $39(52.0 \%)$ & $19(25.3 \%)$ & $75(100 \%)$ & \\
\hline
\end{tabular}

Tabela 4. Comparison of anal canal cytology findings and margin and anal canal High-Resolution Anoscopy one-month posttreatment of margin and/or anal canal lesions.

\begin{tabular}{lcccccc}
\hline \multirow{2}{*}{ Group } & \multicolumn{2}{c}{ Positive HRA } & \multicolumn{2}{c}{ Negative HRA } & & \\
\cline { 2 - 5 } & $\begin{array}{c}\text { Positive } \\
\text { Cytology }\end{array}$ & $\begin{array}{c}\text { Negative } \\
\text { Cytology }\end{array}$ & $\begin{array}{c}\text { Positive } \\
\text { Cytology }\end{array}$ & $\begin{array}{c}\text { Negative } \\
\text { Cytology }\end{array}$ & Total & $p$ \\
\hline I & 8 & 3 & 8 & 1 & $20(26.3 \%)$ & \\
II & 21 & 4 & 6 & 6 & $37(48.7 \%)$ & 0.468 \\
\hline Total & $37(48.7 \%)$ & $10(13.2 \%)$ & $19(25.0 \%)$ & $10(13.2 \%)$ & $76(100 \%)$ & \\
\hline
\end{tabular}


Assessing the results of CytoHRA and PCR, there was moderate Kappa-Cohen agreement $(\mathrm{k}=0.286)$, and a difference in the frequencies found in group III in relation to the other groups $(p=0.042)$. There was no positive HRA or cytology when the PCR was negative. Likewise, all 45 positive HRA had viral types on PCR (Table 5), and the only two cases of histologic HSIL had oncogenic types on PCR.

Sensitivity, specificity, negative and positive predictive values and accuracy of both anal cytology and HPV genotyping are depicted in table 6.

Table 5. Comparison between the presence of HPV types detected by PCR and the finding of anal lesions by cytology and/or High-Resolution Anoscopy after treatment of margin and / or anal canal lesions.

\begin{tabular}{|c|c|c|c|c|c|c|c|}
\hline \multirow{2}{*}{ Group } & \multicolumn{3}{|c|}{ Positive CytoHRA } & \multicolumn{3}{|c|}{ Negative Anal CytoHRA } & \multirow{2}{*}{$p$} \\
\hline & PCR-O & PCR-NO & PCR-N & PCR-O & PCR-NO & PCR-N & \\
\hline I & $7(41.2 \%)$ & $2(11.8 \%)$ & $0(0.0 \%)$ & $2(11.8 \%)$ & $3(17.6 \%)$ & $3(17.6 \%)$ & \\
\hline$\|$ & $24(63.2 \%)$ & $2(5.3 \%)$ & $0(0.0 \%)$ & $7(18.4 \%)$ & $2(5.3 \%)$ & $3(7.9 \%)$ & 0.042 \\
\hline III & $8(42.1 \%)$ & $2(10.5 \%)$ & $0(0.0 \%)$ & $9(47.4 \%)$ & $0(0.0 \%)$ & $0(0.0 \%)$ & \\
\hline Total & $39(52.7 \%)$ & $6(8.1 \%)$ & $0(0.0 \%)$ & $18(24.3 \%)$ & $5(6.8 \%)$ & $6(8.1 \%)$ & 74 \\
\hline
\end{tabular}

Tabela 6. Comparison between diagnostic methods in one month after treatment of margin and / or anal canal lesions.

\begin{tabular}{lccccc}
\hline & Cytology & HRA & CytoHRA & PCR & CytoHRA + PCR \\
\hline Sensitivity & $84.9 \%$ & $100 \%$ & $100 \%$ & $100 \%$ & $100 \%$ \\
Specificity & $29.5 \%$ & $75 \%$ & $73.2 \%$ & $14.3 \%$ & $14.6 \%$ \\
PPV & $46.5 \%$ & $75 \%$ & $75 \%$ & $46.3 \%$ & $46.9 \%$ \\
NPV & $72.2 \%$ & $100 \%$ & $100 \%$ & $100 \%$ & $100 \%$ \\
Accuracy & $52.2 \%$ & $85.7 \%$ & $85.1 \%$ & $50.7 \%$ & $51.4 \%$
\end{tabular}

HRA - High-Resolution Anoscopy; CytoHRA - Association between anal cytopathologic exam and High-Resolution Anoscopy; PCR - polymerase chain reaction; PPV - Positive predictive value; NPV - Negative predictive value.

\section{DISCUSSION}

The present research aimed to compare HPV genotyping by PCR to HRA, HRA-guided biopsy and cytology after one month of eradication of marginal and anal canal condylomata acuminata. The available literature describes the examinations as diagnoses of AIN or condylomas, or as a screening for AIN and anal SCC. To our knowledge, this is the first study that has followed-up those patients treated for such lesions.
There is currently no consensus regarding the follow-up of patients after CA eradication. As far as we know, guidelines do not agree on the first workup or periodicity of assessments, usually ranging from three to six months ${ }^{1,7}$. Follow-up of SIL can be comparable since these lesions share aetiology factors with CA. However, the latest guideline updates, from the American Society of Colon and Rectal Surgeons (ASCRS) $^{6}$ and the German-Austrian consensus ${ }^{4}$ recommend AINs to be followed every three or six 
months according to the type of presented dysplasia. However, those guidelines diverge from the protocols followed by Institutes with great experience treating anal HPV in the United States ${ }^{8-11}$. Due to the difficulty to differentiate remnant lesions from recurrence and from reinfection, our group believes that one month is a more appropriate interval for the evaluation of the recurrence of subclinical lesions, so we have indicated these earlier follow-up after the eradication of visible $C \mathrm{C}^{3}$. It is a convalescence period, when the patient is unlikely to be reinfected, since most likely he has not had sexual intercourse after the treatment yet, and wound healing is mature enough so the scars cannot be mistaken by viral lesions ${ }^{12}$.

HIV, in addition to the known effects on systemicimmunity, also reduces local perianalimmunity ${ }^{12}$. The introduction of HAART, and its availability in the Brazilian public health system, allowed the increased survival of HIV-positive subjects to demonstrate the effects of chronic HPV infection ${ }^{13-15}$. Despite what is expected, HAART does not seem to be associated with a reduction in the risk for SCC. Actually, the literature shows a progressive increase in the incidence of anal SCC in individuals with risk factors, reaching values similar to those of SCC of the cervix prior to the Pap test ${ }^{6,14,16}$. For this population, progression of latent HSIL infection may reach $50 \%$ in two years, and the risk of progression to life-threatening invasive cancer ranges from 10 to $50 \%$ 6,7.

The immunosuppressed MSM population, including those with HIV, is at increased risk for anal SCC and its precursors ${ }^{17,18}$. That risk increases when the individual presents anal warts ${ }^{19}$. Since the risk of recurrence of the verrucous lesions is high, and there are recommendations as to screen them for SCC, we opted to follow these patients after the initial treatment.

In our study, HIV positive participants are older than the seronegative ones. We think this is related to the peculiarities of our Infectious Diseases care: HIV-seropositive individuals have been followed since their initial diagnosis of the viral infection in the IIER infectology clinic and referred to the colorectal department when presenting perianal lesions, while seronegatives were referred from the primary care system to our outpatient clinic. Some authors report that rates of HPV infection in men remain stable throughout life $^{20}$, as well as high levels of sexual activity with new partners may contribute to the high prevalence and non-reduction of anal HPV infections in older men who have sex with men ${ }^{21}$. Therefore, more than just persistent infection, these individuals have high rates of newly acquired HPV ${ }^{21}$.

As shown in Chart 2, histopathological examination confirmed diagnosis of SIL in $73.2 \%$ of the HRA acetowhite lesions, similar to that found in the literature ${ }^{12}$. Data from a review by Schim van der Loeff et al. ${ }^{18}$ in 2014 referred to HSIL incidence rates between $3.3 \%$ in HIV seronegatives and $15.4 \%$ in HIV-positive MSM, percentages close to our results. The number of these findings, however, was very low for statistical difference and to support decision making.

Regarding the cytopathological reports with HRA characteristics of the individuals, we had a correlation in roughly half $(53.3 \%)$ of the cases. Of these, $20 \%$ also had negative PCR. The sensitivity of the latter method, close to $90 \% 22$ and $100 \%$ in this study, is higher than the sensitivity of anal cytology, described as high as $75 \% \%^{22,23}$ and seen in our statistics as $84.9 \%$. An interesting contribution to posttreatment followup can be made by the introduction of PCR, when we consider that the gold standard, HRA-guided biopsy, is not yet available for a large part of the population, and some of those individuals could benefit from it.

The finding of HPV 6 as the most frequent viral type corroborates previous findings as the volunteers of this study were previously treated by perianal condylomas ${ }^{24}$. Type 16, most frequently associated with HPV-induced neoplasms, was found in about $29 \%$ of the subjects, percentages close to the $39 \%$ as seen by Nishijima et al. ${ }^{14}$, and $31,5 \%$ by Hidalgo-Tenorio et al. ${ }^{22}$, both during SCC screening.

HIV patients had a higher incidence of oncogenic types, regardless of the CD4 count, in agreement with data from the group at the University of San Francisco ${ }^{25,26}$. We found similar results when comparing oncogenic HPV in $35.3 \%$ of the seronegatives for HIV, with statistical difference for HIV-positive.

We did not diagnose the HPV types of the treated lesions prior to the inclusion of the volunteers in 
the study, which, together with the small sample size, may be a limiting factor of the present study. However, as demonstrated by several authors ${ }^{24,26}$, the etiological factor of anal condylomata is HPV, and that authorizes the omission of HPV-genotyping for the treatment and the presumption that the patient with this wart lesion is a carrier of the virus in the region. Besides that, the treatment does not change according to the virus type. D'Ambrogio et al. ${ }^{24}$ report that viral types 6 and 11 are more related to condyloma recurrence. In this context, we suppose that the detection of certain types in post-treatment PCR suggests a closer follow-up of the patients in whom they were detected. Therefore, the sequence of this research should bring such answers.

We found a great correlation between the negative comparing CytoHRA tests and PCR. The literature reports up to $100 \%$ negative predictive value (NPV) for PCR in the detection of anal canal infection by $H{ }^{22}$. This test seems to be promising in the exclusion of local disease by this virus, both in the screening for SCC and in post-eradication disease follow-up. We can suggest that the patients should initially be followed up by PCR, after 30 days of eradication of the lesions, reserving HRA for the positive cases.

We found a similarity between the histopathological and genotypic findings for HPV. The NPV of PCR in this study was $100 \%$, and despite the low number of cases, we should consider it to discard the remaining HPV-induced lesions in the selection of patients to perform HRA. A follow-up study of these individuals may also suggest whether a negative HPV DNA test influences the recurrence of lesions and, consequently, the modification of the follow-up offered to them.

We performed HRA in all of the patients as a form of post-treatment eradication control. For those who are referred for screening, this is not the standard practice of the IIER colorectal service. In these cases, we collected two samples with an anal canal brush for cytology. There is a recommendation for HRA for patients with abnormal cytology findings, individuals with cytologic findings of $\mathrm{HSIL}, \mathrm{LSIL}, \mathrm{ASC}-\mathrm{H}$, and ASCUS ${ }^{27}$. If local resources are limited, HSIL and ASC-H take precedence over other findings ${ }^{27}$.

Patients presenting lesions suggestive of anal canal HPV infection are accepted as carriers of the virus at the site $^{28}$. In the absence of clinical and HRA lesions at the first examination in post-eradication follow-up, our current option is to follow only with cytological examination. Although repeating the examination only if we find high grade cytological lesions, as we can see in the present case series and in the rest of the IIER team, there is disagreement between the cytological and HRA findings. We believe that the detection of HPV by PCR might be helpful in the setting of screening the individuals to perform the HRA examination in the post-eradication follow-up of condylomata, improving the flaws of our ongoing protocol.

Periodic follow-up of these patients may bring more information about virus clearance after local ablative treatment and may assist in the study of the development of HPV-induced lesions. Knowledge of the characteristics of individuals who develop highgrade lesions and those that eliminate HPV viral load is the pathway for the development of protocols that allow the treatment of infection of the anal region by HPV to be personalized.

\section{CONCLUSION}

The association of HPV cytopathology, HRA and HPV genotyping by PCR increased the diagnostic sensitivity of HPV-induced lesions after treatment of anal condyloma. Also, PCR genotyping provides findings corresponding to those of anal HRA. In our study, the severity of immunodeficiency was not associated with the increase of the remnant HPVinduced anal lesions.

\section{Compliance with ethical standards}

Funding: This study was financed in part by the Coordenação de Aperfeiçoamento de Pessoal de Nível Superior - Brasil (CAPES) - Finance Code 001

Conflict of interest: The authors declare that they have no conflict of interest.

Acknowledgements: Luisa Lina Villa and Barbara Mello, from the Institute for Cancer Research at the University of Sao Paulo for the HPV DNA analyses. 


\title{
R E S U M O
}

\begin{abstract}
Objetivo: avaliar a presença de lesões anais subclínicas HPV-induzidas com citologia anal, colposcopia anal e genotipagem de HPV por reação em cadeia da polimerase (PCR) no seguimento de condilomas anais tratados. Método: foram incluídos 79 pacientes do sexo masculino. Após um mês da erradicação de lesões condilomatosas anais, os participantes voltaram em consulta para coleta de amostras com escova para citologia anal e PCR, e colposcopia anal com biópsia de lesões acetobrancas. Os métodos de detecção das lesões foram comparados entre os pacientes e entre grupos, de acordo com o status de infecção pelo vírus da imunodeficiência humana (HIV): HIV-negativo; HIV-positivo com TCD4 acima ou abaixo de 350 células/mm3. Resultados: os tipos de HPV mais frequentes foram 6 e 16. Infecção pelo HIV foi associada a maior número de tipos de HPV oncogênicos ( $p=0,038)$. Todos os pacientes com PCR negativo apresentaram colposcopia e citologia negativos. Não houve diferença nos achados citológico, colposcópico ou histopatológico entre grupos. Conclusão: a associação dos achados citopatológico, colposcópico e PCR melhorou a acurácia do diagnóstico de lesões anais HPV-induzidas. O grau de imunodeficiência não foi associado a maior frequência de lesões anais HPVinduzidas remanescentes.
\end{abstract}

Palavras chave: Testes de DNA para Papilomavirus Humano. Condiloma Acuminado. Neoplasia do Ânus. Reação em Cadeia da Polimerase. Transformação Celular Viral.

\section{REFERENCES}

1. Gormley RH, Kovarik CL. Human papillomavirusrelated genital disease in the immunocompromised host: Part I. J Am Acad Dermatol [Internet]. 2012 Jun [cited 2019 Mar];66(6):867.e1-14. Available from: https://linkinghub.elsevier.com/retrieve/pii/ S0190962211008140

2. Vela S, Videla S, Ornelas A, Revollo B, Clotet B, Sirera $G$, et al. Effectiveness of physically ablative and pharmacological treatments for anal condyloma in HIV-infected men. PLoS One [Internet]. 2018 Aug [cited 2019 Mar];13(8):e0199033. Available from: https://dx.plos.org/10.1371/journal.pone.0199033

3. Manzione T da S, Nadal SR, Calore EE, Nadal LRM, Manzione CR. Local control of human papillomavirus infection after anal condylomata acuminata eradication. Rev Col Bras Cir [Internet]. 2014 Mar-Apr [cited 2019 Mar];41(2):87-91. Available from: $\quad$ http://www.scielo.br/scielo.php?script=sci_ arttext\&pid=S0100-69912014000200087\&lng=en\& tlng=em

4. Esser S, Kreuter A, Oette M, Gingelmaier A, Mosthaf F, Sautter-Bihl M-L, et al. German-Austrian guidelines on anal dysplasia and anal cancer in HIV-positive individuals: prevention, diagnosis, and treatment. J Dtsch Dermatol Ges [Internet]. 2015 Dec [cited 2019 Mar];13(12):1302-19. Available from: http://doi. wiley.com/10.1111/ddg.12726

5. Alam NN, White DA, Narang SK, Daniels IR, Smart NJ. Systematic review of guidelines for the assessment and management of high-grade anal intraepithelial neoplasia (AIN II/III). Colorectal Dis. 2016;18(2):13546.

6. Stewart DB, Gaertner WB, Glasgow SC, Herzig $D O$, Feingold D, Steele SR; Prepared on Behalf of the Clinical Practice Guidelines Committee of the American Society of Colon and Rectal Surgeons. The American Society of Colon and Rectal Surgeons Clinical Practice Guidelines for Anal Squamous Cell Cancers (Revised 2018). Dis Colon Rectum [Internet]. 2018 Jul [cited 2019 Mar];61(7):755-74. Available from: http://journals.Iww.com/00003453201807000-00002

7. Siddharthan R, Lanciault C, Tsikitis VL. Anal intraepithelial neoplasia: diagnosis, screening, and treatment. Ann Gastroenterology [Internet]. 2019 May-Jun [cited 2019 Mar];32(3):257-63. Available from: http://www.annalsgastro.gr/files/journals/1/ earlyview/2019/ev-02-2019-06-AG4428-0364.pdf

8. Crawshaw BP, Russ AJ, Stein SL, Reynolds $\mathrm{HL}$, Marderstein EL, Delaney $C P$, et al. High-resolution anoscopy or expectant management for anal intraepithelial neoplasia for the prevention of anal cancer. Dis Colon Rectum [Internet]. 2015 Jan [cited 2019 Mar];58(1):53-9. Available from: http:// content.wkhealth.com/linkback/

9. Fazendin EA, Crean AJ, Fazendin JM, Kucejko RJ, Gill HS, Poggio JL, et al. Condyloma Acuminatum, anal intraepithelial neoplasia, and anal cancer in the setting of HIV: do we really understand the risk? Dis Colon Rectum [Internet]. 2017 Oct [Cited 2019 Mar];60(10):1078-82. Available from: http://journals. Iww.com/00003453-201710000-00013 
10. Chin-Hong PV, Palefsky JM. Natural history and clinical management of anal human papillomavirus disease in men and women infected with human immunodeficiency virus. Clin Infect Dis [Internet]. 2002 Nov [cited 2019 Mar];35(9):1127-34. Available from: http://www.ncbi.nlm.nih.gov/entrez/query.

11. Echenique I, Phillips BR. Anal warts and anal intradermal neoplasia. Clin Colon Rectal Surg. $2011 ; 24(1): 31-8$.

12. Messick CA, Rodriguez-Bigas MA. Anal Dysplasia. Surg Oncol Clin N Am [Internet]. 2017 Nov [cited 2019 Mar];26(1):33-43. Available from: http://dx.doi. org/10.1016/j.soc.2016.07.005

13. Libois A, Feoli F, Nkuize M, Delforge M, Konopnicki $D$, Clumeck N, et al. Prolonged antiretroviral therapy is associated with fewer anal high-grade squamous intraepithelial lesions in HIV-positive MSM in a cross-sectional study. Sex Transm Infect [Internet]. 2017 Feb [cited 2019 Mar];93(1):15-7. Available from: http://sti.bmj.com/lookup/doi/10.1136/ sextrans-2015-052444

14. Nishijima T, Nagata N, Watanabe K, Sekine K, Tanaka $S$, Kishida $Y$, et al. HIV-1 infection, but not syphilis or HBV infection, is a strong risk factor for anorectal condyloma in Asian population: A prospective colonoscopy screening study. Int J Infect Dis [Internet]. 2015 Aug [cited 2019 Mar];37:70-6. Available from: http://dx.doi.org/10.1016/j.ijid.2015.06.009

15. Rubinstein PG, Aboulafia DM, Zloza A. Malignancies in HIV/AIDS: from epidemiology to therapeutic challenges. AIDS [Internet]. 2014 Feb [cited 2019 Mar];28(4):453-65. Available from: http://journals. Iww.com/00002030-201402200-00001

16. Egawa N, Egawa K, Griffin H, Doorbar J. Human papillomaviruses; Epithelial tropisms, and the development of neoplasia. Viruses. 2015;7(7):386390.

17. Machalek DA, Poynten IM, Jin F, Hillman RJ, Templeton D, Law C, Roberts JM, Tabrizi SN, Garland SM, Farnsworth A, Fairley CK, Grulich AE; SPANC study team. A composite cytology-histology endpoint allows a more accurate estimate of anal high-grade squamous intraepithelial lesion prevalence. Cancer Epidemiol Biomarkers Prev. 2016;25(7):1134-43.

18. Schim van der Loeff MF, Mooij SH, Richel O, de
Vries HJ, Prins JM. HPV and anal cancer in HIVinfected individuals: a review. Curr HIVIAIDS Rep. 2014;11(3):250-62.

19. McCutcheon $T$, Hawkins AT, Muldoon RL, Hopkins MB, Geiger TM, Ford MM. Progression of anal intraepithelial neoplasia in HIV-positive individuals: predisposing factors. Tech Coloproctol [Internet]. 2019 Apr [cited 2019 Mar];23(4):325-32. Available from: http://link.springer.com/10.1007/s10151-01901951-w

20. Ingles DJ, Lin HY, Fulp WJ, Sudenga SL, Lu B, Schabath $M B$, et al. An analysis of HPV infection incidence and clearance by genotype and age in men: The HPV Infection in Men (HIM) Study. Papillomavirus Res [Internet]. 2015 Dec [cited 2019 Mar];1:12635. Available from: https://linkinghub.elsevier.com/ retrieve/pii/S2405852115000154

21. Poynten IM, Machalek D, Templeton D, Jin F, Hillman $R$, Zablotzska I, et al. Comparison of age-specific patterns of sexual behaviour and anal HPV prevalence in homosexual men with patterns in women. Sex Transm Infect [Internet]. 2016 May [cited 2019 Mar];92(3):228-31. Available from: http://sti.bmj. com/lookup/doi/10.1136/sextrans-2015-052032

22. Hidalgo-Tenorio C, Rivero-Rodriguez M, Gil-Anguita C, Esquivias J, López-Castro R, Ramírez-Taboada $J$, et al. The role of polymerase chain reaction of high-risk human papilloma virus in the screening of high-grade squamous intraepithelial lesions in the anal mucosa of human immunodeficiency viruspositive males having sex with males. PLoS One. 2015; 10(4):e0123590.

23. Nadal SR, Calore EE, Nadal LRM, Horta SHC, Manzione CR. Citologia anal para rastreamento de lesões pré-neoplásicas. Rev Assoc Med Bras [Internet]. 2007 Apr[ cited 2019 Mar];53(2):147-51. Available from: http://www.scielo.br/scielo.php?script=sci_ arttext\&pid=S0104-42302007000200020\&lng=pt\& nrm=iso\&tlng=PT

24. D'Ambrogio A, Yerly $S$, Sahli R, Bouzourene $H$, Demartines $N$, Cotton $M$, et al. Human papilloma virus type and recurrence rate after surgical clearance of anal condylomata acuminata. Sex Transm Dis. 2009;36(9):536-40.

25. Berry JM, Palefsky JM, Jay N, Cheng SC, Darragh 
TM, Chin-Hong PV. Performance characteristics of anal cytology and human papillomavirus testing in patients with high-resolution anoscopy-guided biopsy of high-grade anal intraepithelial neoplasia. Dis Colon Rectum. 2009;52(2):239-47.

26. Berry JM, Jay N, Palefsky JM, Welton ML. State-of-theArt of high-resolution anoscopy as a tool to manage patients at risk for anal cancer. Semin Colon Rectal Surg [Internet]. 2004 Dec[cited 2019 Mar];15(4):21826. Available from: https://linkinghub.elsevier.com/
retrieve/pii/S1043148905000345

27. Krishnamurti $U$, Unger ER. Pathobiology of human papillomaviruses in human immunodeficiency virus - Infected persons. Semin Diagn Pathol [Internet]. 2017 Jul [cited 2019 Mar];34(4):364-70. Available from: https://linkinghub.elsevier.com/retrieve/pii/ S0740257017300461

28. Gal AA, Meyer PR, Taylor CR. Papillomavirus antigens in anorectal condyloma and carcinoma in homosexual men. JAMA. 1987;257(3):337-40.
Received in: 26/03/2019

Accepted for publication: 15/05/2020

Conflict of interest: no.

Funding source: none.

\section{Mailing address:}

Luis Roberto Nadal

E-mail: Irnadal@gmail.com

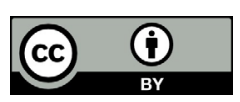

